\title{
The filter is so much more fragile when you are queer
}

Catherine Baker

University of Hull

cbakertw1@googlemail.com

June, 2016: We are gathered round a cenotaph in hundreds, a rainbow Union flag crossed over with a rainbow Stars and Stripes, standing in a vigil like queers in a dozen other UK cities remembering the 49 mainly Latino and mainly queer dead, everyone from brighthaired teenagers to merchant-navy queens and weathered dykes. A thought occurs to me: this is more queers together than l've ever seen in Hull.

November, 2016: I am awake and the Americans are asleep but the Americans I love best and respect most are too anxious to sleep either. They are drawing and scribbling and tweeting fear and defiance, planning escapes, standing their ground, listing what medications to stockpile and what papers to get in order before a vice-president who believes in gay and trans conversion therapy and a president who seems to believe in nothing but raw masculine white power begin to wrench their partial, limited scraps of equality away. Before the queer creativity that finally gloriously found a space to flourish has to fight so much harder not to be forced back into silence after all.

In the days following his victory, the British media and my straight co-workers are still at How could he even win? But if nationhood means experiencing the same emotions at the same times then the alarm that stretches out from queers to queers along the oceanic cables we take for granted and drips its sea-monstrous way up from the shore is just like after Orlando: something diasporic, but this time rather than a collective grieving for names 
we would probably never otherwise have known, it has to foretell future mourning, for names we might not even be allowed to hear.

Queer lives that are lived digitally and transatlantically in a space which itself might not survive the restrictions on organisation and expression that could be in store for Americans - like Russians and Turks and Egyptians before them, like Chileans and Iranians and Argentinians all before that, often in coups that suited the US government interests of the time - cascade down new online platforms and tumble through abandoned old ones, pulsing timelines and lingering forums of friends and colleagues and is there a word for people whose identities re-formed at the same time as yours but whose names these days you might not even know?

A thought occurs: There are people I know or used to know who will be dead in four years' time.

That's just alarmist. Don't be so overdramatic! Of course it won't be as bad as that.
Something in your stomach and the back of your throat still tells you that it can.

What queers know, like migrants know, like anybody with a womb will know, is how easily freedoms can disappear.

You feel it. 
Maybe only deep in the background sometimes, inside white skin and an able body that lulls you into forgetting how unequally distributed those freedoms already are. Or maybe screaming violently in front of you, when you've chosen to risk some of them or when history took that choice away from you before you were even born.

When I try to theorise a 'queer aesthetic curiosity' towards world politics, or try to explain what a trans woman's writing about gender is likely to convey that a cis woman's almost always can't, I call that feeling things like embodied knowledge. It lives in the feet and the shoulders and the untroubled stomach. It lives in the ring-fingers and the retinas and the thighs. Something about your body and how you live in it - your queerness - and where on the planet you are doing whatever you are doing means that you at least think about in/security, sometimes, in the everyday, in a way that a straight white man living somewhere as a citizen has under normal, peacetime circumstances never considered that he would have to do.

You think about it because others have felt it and you thought you might feel it and stories of progress told you that you might not have to. Every legal victory that activists won in America or Europe - every piece of pride that started being taken over 'equality' in the name of the nation forgetting how many of the same nation's laws and police officers had been standing in equality's way - helped tell a story about time.

The UK, 1990s: Things can only get better, sang the first Blair government, charged with implementing European court judgements on gays in the military and an equal age of consent. It gets better. You were born this way. 
Weimar Berlin, 1930s: hundreds of men and women and others who loved people they never used to think that they could touch, presented themselves to the world in ways they'd never seen, found out about the surgery and care that would make their bodies seem more like themselves and that had never been more advanced than at this time, right now, and whose lives and notes and names were about to go up in smoke when the stormtroopers burned Magnus Hirschfeld's library.

Russia, 2000s: The tone-altering epilogues to more than one book, researched during the 1990s and/or 2000s and (re)published after 2013, on how space for gays and lesbians to define themselves after the silences of communism was tentatively finally opening up in Russia.

The line between bodily autonomy and losing it for queer people is called politics. The same line for cis, straight people is called dystopia.

There are freedoms I have in England or would have in America, which I didn't even expect to enjoy as a teenager but which my queer elders won for me. In doing so, I gained a strange kind of everyday security with an uncanny contingency underneath - which I could lose again in ways that, if they were proposed for straight people, would be the stuff of dystopia, 'some Handmaid's Tale shit right there'.

(Dystopia still happens. But it takes so many more guns.)

Imagine, as a straight, cisgender man or woman, watching an election knowing that the result could determine whether you were allowed to stay married to your husband or wife. Or imagine knowing that the government looming into power could force you, as a man, to 
live life as a woman, or force you, as a woman, to live life as a man, an outcome almost inconceivable if you're not trans.

Security is unimaginability. A protective barrier constructed out of it-can't-happen-here. A firm belief that even when it's happened to other people, even when your own country has made it happen to other people, you can be certain in your nerves and in your bones that it can't, it couldn't happen to you.

And when you have that certainty and I can't share it, even across our shared whiteness or our shared politics or our shared class, a boundary between us starts to have political meaning it didn't have before, and identity becomes a matter of in/security.

I know without having lived it that ethnopolitical conflict works like that.

The anxieties over 'dilution' or 'undermining' national cultural values that racists and xenophobes intensify in order to mobilise public support for restricting immigration work like that.

Queerness as a political identity works like that, too.

Studying the Yugoslav wars since my early twenties, when all that preoccupied me at the time they were happening was making sense of the confusion with which I entered my own queer teens: I know identities wax strongest, turn from individual to collective, description to politics, when people believe or are led to believe that that identity is why they're under threat. 
I know it through compressing acres of wartime newsprint into weeks of research, through collecting hours upon hours of memories, through years of friendship and listening and solidarity, all breaking down my own filter of it-can't-happen-here.

Or so I thought: but the filter is already so much more fragile when you are queer. 